\title{
The Effectiveness of Health Promotion in Reducing of Skabies In The Islamic Boarding School
}

\author{
Indriati, Tutik Setyowati, M. Zainal Abidin \\ Poltekkes Kemenkes Semarang, Indonesia \\ Corresponding author : iinbimi1234@gmail.com
}

\begin{abstract}
Background: The results of interviews with the School Health Unit in 3 Islamic boarding schools (pesantren) in Blora City District showed that $75 \%-90 \%$ of santri had been exposed to scabies.

Purpose: This study aims to analyze the effectiveness of health promotion in reducing the incidence of scabies

Methods: Interventions in the form of health promotion (counseling, and community development). Independent health promotion variables, the dependent variable is the incidence of scabies, the variable between knowledge, attitude, and behavior. The research design is quasi-experimental one group (pretest-posttest). Place of research for Islamic boarding schools in Blora City District. The research population of the santri was a sample of students in grades 8 and 9. Proportional random sampling sampling technique. The intervention is carried out on August, 26, 2018 until October, 23, 2018.

Result: Mean knowledge, attitude, and behavior before intervention 69.76; 69.86; 54.65. After intervention 87,18; 88.06; 63.35. P Value of knowledge, attitudes, and behavior = 0.00 ; meaning that there are differences in knowledge, attitudes, and behaviors before and after the intervention. Before the intervention students were exposed to 128 scabies (75.29\%) and after intervention 5 people (2.94\%). There is a difference in the proportion of scabies before and after the intervention with $\mathrm{P}$ Value $=0.00$

Conclusion: Health promotion is effective in reducing the incidence of scabies in Islamic boarding schools in Blora City.
\end{abstract}

Keywords: Scabies, Student Islamic Boarding Schools, Clean Behavior Lifestyle

Received July, 25, 2019; Revised August 24, 2019; Accepted September 13, 2019

How to Cite: Indriati., Setyowati, T., Abidin, M.Z. (2019). The Effectiveness of Health Promotion in Reducing of Skabies In The Islamic Boarding School. Journal Of Nursing Practice, 3(1), 8-13. https://doi.org/10.30994/jnp.v3i1.60 


\section{BACKGROUND}

Islamic Boarding Schools are educational institutions that have the best curriculum and system. Not only armed with worldly knowledge, pesantren also teach ukhrawi knowledge. Students will be forged maximally and intensively. In the pesantren also inserted the meanings of discipline, besides being useful as a school, Islamic boarding schools are also used as a place of residence for the santri. Therefore, the health of santri and the environment around Islamic boarding schools is a very important thing in implementing community care.

The health of santri can be maintained by a clean and healthy lifestyle. Many diseases can be avoided by clean healthy life behaviors, including scabies (scabies). Scabies or commonly known as scabies / gudig (in indonesia) is a disease caused by mites, sarcoptes scabei, which is in the lower canal of the skin. Scabies transmission can be through direct contact with patients and indirectly between exchanging towels, pillows, and other sheets. Scabies usually only causes discomfort due to skin rashes / itching. Secondary bacterial infections due to frequent and tight scratching can cause impetigo, abscesses, cellulitis, and septicemia to even cause death (Handoko, 2007)

The results of interviews with the UKS section in three Islamic boarding schools in Blora City District showed that $75 \%$ to $90 \%$ of female students had been exposed to scabies. This could happen because students do not know how to prevent and transmit scabies, health workers or huts are not maximal in conveying the importance of clean healthy living behavior, or maybe students of Islamic boarding schools that have not implemented clean healthy lifestyle.

\section{OBJECTIVE}

This study aimed to analyze the effectiveness of health promotion in reducing the incidence of scabies.

\section{METHODS}

Type of quasi-experimental quantitative research (Quasi experimental) with one group (pretest-posttest) design research design. Place of research for Islamic boarding schools (Islamic boarding schools) in Blora. The study population was all santri in Blora Kota District. The research sample was some santri from Islamic boarding schools in Blora Subdistrict and fulfilled the inclusion criteria, namely students who stayed overnight or spent the night in boarding schools, recorded as active students or students in grades 8 or 9 in SMP or MTS, agreed to be involved in research. In Blora Kota District, there are 11 Islamic boarding schools, seven of which have students in grades 8 and 9.

The researcher used proportional random sampling sampling technique. By using the Taro Yamane formula, the researcher determines the number of Islamic boarding schools that will be used as research sites and the number of samples from each Islamic boarding school. After being calculated, the seven Islamic boarding schools were used as research sites and the total sample was 170. The seven Islamic boarding schools were Banjari, Khozinatul Ulum, Nurul Istiqomah, Roudhotul Falah, An Nur, Al Hikmah, and Al Ikhlas.

This study consisted of three variables, namely the independent variable (health promotion / health promotion), the dependent variable (incidence of scabies), the intermediate variable (knowledge, attitudes and behaviors of scabies prevention). Health promotion is a process of health education, community empowerment, and assistance to santri and fostering an atmosphere towards the management of Islamic boarding schools so that students are able to maintain and improve their own health by having clean and healthy knowledge, attitudes 
and behaviors to avoid scabies. Data types: categorical (nominal). The incidence of scabies is divided into two, before and after health promotion. The occurrence of scabies before health promotion is the number of scabies occurrences suffered by santri in the last three months before counseling, mentoring, and fostering the atmosphere. Diagnosis of scabies is enforced by a doctor. The occurrence of scabies after health promotion is the number of scabies occurrences suffered by santri after counseling, mentoring, and atmosphere building. Diagnosis of scabies is enforced by a doctor.

The instrument of this research is a questionnaire. There are two types of questionnaires, namely pre and post health promotion questionnaires. Each questionnaire contains 4 parts. Part A asks for the identity of the respondent (name, age, class, and name of the boarding school). Part B asks about the incidence of scabies. Part $\mathrm{C}$ to find out the knowledge of respondents, consists of 10 questions. Each question is worth 10 if the respondent correctly answers it and is worth 0 if the respondent incorrectly answers it. Part D to find out the attitude of the respondents, consisting of 10 questions. Each question is worth 10 if the respondent correctly answers it and is worth 0 if the respondent incorrectly answers it. Part $\mathrm{E}$ to find out the behavior of respondents, consists of 12 questions. Each question is worth 10 if the respondent correctly answers it and is worth 0 if the respondent incorrectly answers it.

The researcher used a paired $\mathrm{T}$ test to find out the mean differences in knowledge, attitudes, and behaviors before and after treatment. The paired $\mathrm{T}$ test is used when paired data and its scale are measured in intervals or ratios (numerical data types). If the assumptions are not met (data is not normally distributed), then use the Wilcoxon test (Dharma, 2011). The researcher used the Chi square test to determine the proportion of the incidence of scabies before and after health promotion. Chi square is used to test different proportions (nominal data) of 2 events. If the expected value $<5$ in more than $20 \%$ of the cell numbers, then the Fisher exact test is used.

The participants were assured that their engagement was voluntary, and that anonymity, privacy, and confidentiality of the data were guaranteed. Furthermore, they were informed about the purpose and the method of the study before signing a written informed consent. The questionnaires were distributed to eligible participants at the Islamic boarding schools in Blora, and respondents were asked to complete and return them in the same time.

\section{RESULTS}

The results showed the mean (knowledge) of respondents' knowledge before intervention 69.76 and after intervention 87.18. The mean score before the intervention was 69.86 and after the intervention 88.06. The mean value of the respondent's behavior before intervention was 54.65 and after intervention 63.35.

The results of the study describe the average value of respondents' knowledge about scabies before health promotion 69.76. This means that respondents have sufficient knowledge about scabies.

The results showed an increase in the value of the average knowledge of respondents after health promotion compared to before health promotion, namely from 69.76 to 87.18 . The results also showed that there were differences in knowledge before and after health promotion, with a value of $\mathrm{p}$ Value 0.00 . The results showed that the average value of respondents' knowledge and attitudes before the intervention was in a fairly good range of 69.76 and 69.86. This means that there is a positive correlation between knowledge and attitudes other than that. The results of the study show that there is an increase in the average 
value of attitudes before and after health education, which is from 69.86 to 88.06 . The results also showed that there were differences in attitudes before and after the intervention with a value of $p$ Value 0.00 . The results showed the mean (mean) value of respondents' behavior before intervention 54.65. If we use the category of knowledge, according to Machfoedz (2009), the value of 0-55 is categorized as less. This is different from the mean of knowledge and attitudes of respondents before being interved which is in the sufficient category. This means that there is a less positive correlation between knowledge and attitudes toward behavior.

\section{DISCUSSION}

The results of the study describe the average value of respondents' knowledge about scabies before health promotion 69.76. This means that respondents have sufficient knowledge about scabies. According to Machfoedz (2009), the level of knowledge of respondents said enough if the subject was able to answer correctly $56-75 \%$ of all statements.

Sufficient level of knowledge is one of the supporting factors for the success of behavior change in a positive direction. This is consistent with Lawrence R Green's theory, which says one of the driving factors (predisposing factors) of behavior is knowledge (Azwar, 2005)

Respondents were 8th and 9th grade students. The respondents' knowledge about scabies was very likely to be obtained from the education bench, According to (Notoatmodjo, 2010), there are several factors that influence a person's knowledge, namely education, mass media, social culture and economy, experience, and environment. Education is an attempt to develop personality and abilities inside and outside school and last a lifetime. The junior high school curriculum contains biology subjects that study the disease and its causes.

In the above, it has been stated that one of the factors that influence knowledge is the mass media. In the current millennial era, many young people access information from digital mass media, including smartphones. Don Tapscott in his book entitled Grown Up Digital: How the Net Generation is Changing Your World, 2008, says that there are currently three generations, namely the baby boomers (born 1946-1964), Generation X (1965-1976), and generation net or net generation born after 1976. Respondents are net generation.

Net generation uses almost instinctive technology. They use the latest smartphones without opening a guidebook compared to the previous generation, with the aim of learning, seeking information, interacting socially, playing, shopping, and so on. Net generation uses technology to solve their problems and find messages that suit their needs.

The results of the research that can be seen from the respondents' answers when filling out the questionnaire stated that the respondents actually already knew that they should not borrow from private property to avoid infectious diseases. They learned that one method of transmission of scabies was through mattresses, sheets, towels and slippers. However, they said that they were used to sleeping with their friends using the same mattress because not all santri had mattresses. The management of Islamic boarding schools does not require every santri to bring one mattress and the boarding school does not provide mattresses.

Respondents also said that they were used to borrowing slippers, especially flip-flops. There are only a few students who have flip-flops. The management of the Islamic boarding school does not require every santri to bring flip-flops, as well as no written rules governing this. Some respondents washed their clothes after using it for more than 2 days, washed the sheets after using them for more than a month, and never even washed pillowcases or bolsters. 
Even though they use bed linen, pillows, and bolsters together. When asked why they said they were lazy to wash it.

The results showed that there was an increase in the average value of behavior before and after health promotion, ie from 54.65 and to 63.35 . The results also showed that there were differences in behavior before and after health promotion with a value of $p$ Value 0.00 . This phenomenon shows that health promotion is able to improve respondents' behavior in a more positive direction. Health promotion is not only oriented to the realm of knowledge, but also oriented to the realm of attitudes and behavior by empowering and fostering an atmosphere. Empowerment is the provision of information and assistance in preventing and overcoming health problems, in order to help individuals, families or community groups undergo stages of knowing, wanting and being able to practice clean and healthy living behaviors.

Building an atmosphere is the establishment of a conducive atmosphere of the social environment and encouraging the practice of clean and healthy life behavior and the creation of role models in adopting clean and healthy life behaviors and preserving them (Ministry of Health, 2011). The creation of role models in adopting clean, healthy lifestyle is one of the reinforcing factors. In Islamic boarding schools, teachers called ustadz and managers or administrators of Islamic boarding schools called kyai or nyai are their role models. They will obey what the ustadz and kyai say (Sami'na Wa atho'na = we hear and we obey). Besides that they will also imitate what the ustadz and kyai do. So teachers and administrators of Islamic boarding schools are key figures for the adoption of clean and healthy life behaviors. Thus it is necessary to conduct health education and assistance in adopting clean and healthy life behaviors with the aim of clerics and clerics. Besides that, it is also necessary to build an atmosphere with them to create a conducive social atmosphere. The results showed a decrease in the incidence of scabies after health promotion, which was from $75.29 \%$ to $2.94 \%$. This is the impact of the increase in respondents' healthy hygiene behavior. After health promotion, respondents did not borrow from each other to borrow personal property, there were cleaning activities at least once a week to clean public facilities, there were daily pickets to clean each room.

\section{CONCLUSION}

There are differences in knowledge before and after intervention; there are differences in attitudes before and after intervention; and there were differences in behavior before and after the intervention. Effective health promotion reduced the incidence of scabies in Islamic boarding schools in Blora City.

Someone who has sufficient knowledge and attitudes towards a clean, healthy lifestyle, will not necessarily practice it in the form of behavior

\section{REFERENCES}

Azwar, S. (2005). Prosedur Penelitian Suatu Pendekatan Praktek, Edisi Revisi V. Yogyakarta: Rineka Cipta

Akmal, S. C., \& Semiarty, R. (2013). Artikel Penelitian Hubungan Personal Hygiene Dengan Kejadian Skabies Di Pondok Pendidikan Islam Darul Ulum, Palarik Air Pacah , Kecamatan Koto Tangah Padang Tahun 2013, 2(3), 164-167

Bodgan, Robert, C, Biklen, S.K. (2006).Qualitative Research for Education: an Introduction to Theories and Methods, Fifth Edition, USA, Pearson. 


\section{Journal Of Nursing Practice}

http://thejnp.org

ISSN: 2614-3488 (print); 2614-3496 (online)

Vol.3 No.1. October 2019. Page.8-13

Bungin, Burhan.(2010). Penelitian Kualitatif: Komunikasi, Ekonomi, Kebijakan Publik, dan Ilmu Sosial Lainnya, Jakarta, Kencana.

Dhofier, Z.(1983). Tradisi Pesantren Studi Tentang Pandangan Hidup Kyai, Jakarta LP3S.

Don Tapscott. (2008). Grown Up Digital: How the Net Generation is Changing Your World. $1^{\text {st }}$ Edition. Publisher: McGraw-Hill Education.

Erika Kusumawardani. (2012). Pengaruh Penyuluhan Kesehatan Terhadap Tingkat Pengetahuan, Sikap, dan Praktek Ibu Dalam Pencegahan Demam Berdarah Dengue Pada Anak. Media Medika Muda.

Fleeson, W., Jayawickreme, E., Jones, A. B. A. P., Brown, N. A., Serfass, D. G., Sherman, R. A., ... Matyjek-, M. (2017). No \{Title\}. Journal of Personality and Social Psychology, 1(1), 1188-1197. https://doi.org/10.1111/j.1469-7610.2010.02280.x

Griana, T. P. (2013). Scabies : Penyebab, Penanganan Dan Pencegahannya. el-Hayah, 4(1). https://doi.org/10.18860/elha.v4i1.2619.

Handoko, R. (2007). Ilmu Penyakit Kulit dan Kelamin, Edisi ke- 5. Jakarta: Fakultas Kedokteran Universitas Indonesia

Ma'rufi I, Istiajai E, Witcahyo E.(2012). Hubungan Perilaku Sehat Santri Dengan Kejadian Skabies Di Pondok Pesantren Kabupaten Lamongan. Ilmu Kesehatan Masyarakat. [ Diunduh tanggal 8 Februari 2014 ].

Ma'rufi I, Keman S, Notobroto H.B.(2005). Faktor Sanitasi Lingkungan Yang Berperan Terhadap Prevalensi Penyakit Skabies, Kesehatan Lingkungan. Juli 2005;2:11-8. [ Diunduhtanggal 31 Januari 2014 ].

Mayasari, ML \& Wahyono, B .(2017). Efektifitas Penyuluhan Kesehatan Dengan Metode Ceramah Disertai Booklet Dalam Upaya Meningkatkan Pengetahuan Ibu Tentang Penyakit Pneumonia Pada Balita Di Kelurahan Bandarharjo Kecamatan Semarang Utara kota Semarang Tahun 2014, journal.unnes.ac.id, Sep 29.

Muslihati, I., Lisandy, Y., Kasanah, R., \& Winarko, H. (2018). Effect Of Education Media Video On Improve Stroke Prevention Behavior In Continued Age In Wiyurejo Pujon Malang. Journal Of Nursing Practice, 1(2), 12-17. https://doi.org/10.30994/jnp.v1i2.28

Notoatmodjo. (2010). Promosi Kesehatan dan Ilmu Perilaku. Jakarta: Rineka Cipta

Ratri, C. P., \& Paskarini, I. (2014). Faktor Yang Berhubungan Dengan Kejadian Scabies Pada Nelayan Di Desa Weru Kecamatan Paciran Kabupaten Lamongan, 1(1), 132143.

Rina, W., \& Indriani, D. (2015). Scabies Infection Control Analysis at Pondok Pesantren ( Boarding School ) Darussalam Banyuwangi District. 